\title{
A Região do Cáspio na estratégia global dos EUA: do engajamento à retirada
}

\author{
The Caspian Region in the global US strategy: \\ from engagement to withdrawal
}

\section{INTRODUÇÃO}

No centro do Cáucaso do Sul e Ásia Central, encontra-se o maior corpo d'água ${ }^{1}$ fechado e interior (cercado por massas terrestres) do mundo, o Cáspio. Suas margens estão limitadas a Nordeste pelo Cazaquistão, a Sudeste pelo Turcomenistão, a Sul pelo Irã, a Sudoeste pelo Azerbaijão, e a Noroeste pela Rússia (ver Mapa 1). O Cáspio e seus arredores ganharam especial atenção com o colapso da URSS em 1991 por causa das suas vastas riquezas fósseis - quantidades significativas de gás natural e petróleo. A região - que esteve sob jugo russo por séculos - foi basicamente esquecida e/ou pouco conhecida durante todo período da Guerra Fria. Com a derrocada soviética, rapidamente diversos Estados e empresas petrolíferas tomaram consciência do grande potencial energético do Cáspio e passaram a investir em projetos na região. Entretanto, o período imediato ao colapso soviético foi caracterizado por uma vantagem esmagadora da Rússia em relação ao trânsito de petróleo e gás na região do Cáspio. Durante o período soviético, toda a infraestrutura de transporte e logística da região do Cáspio era direcionada à zona industrial da URSS - hoje a região europeia da Rússia. Assim, do mesmo modo, o sistema de transporte dos hidrocarbonetos (dutos e ferrovias) fundamentalmente era direcionado à Rússia. Outro fator, não menos importante, durante todo o período soviético as repúblicas da região do Cáspio ficaram totalmente isoladas do resto do mundo - além de não contarem com saídas para o mar, os contatos com os vizinhos externos ao espaço soviético eram mínimos.

Na década de 1990, os EUA procuraram desbloquear os recursos energéticos do Cáspio através da abertura de rotas de exportação que atravessassem países alinhados aos interesses dos EUA — como a Turquia, 
no período - e, sobretudo, evitar o território de adversários estratégicos como a Rússia e o Irã. Um dos elementos-chave da estratégia dos EUA no Cáspio estava em ligar diretamente o mercado europeu ao petróleo e ao gás da região, através de uma rede ramificada de dutos. Desta forma, os EUA esperavam minimizar a influência russa sobre as rotas de transporte de energia na região. Assim, o Cáspio passou da obscuridade para o primeiro plano dos - revisados - cálculos geopolíticos. Enquanto o poder e a influência da Rússia enfraquecia na região, as potências externas - como EUA, China e a União Europeia - aumentavam sua presença político-econômica, e os novos Estados independentes - Azerbaijão, Cazaquistão e Turcomenistão - começavam a traçar caminhos distintos e autônomos ao antigo laço com os eslavos. ${ }^{2}$ (Aydin 2004, 3; Kostianoy, Zonn, and Kostianaia 2016, 11-13; Mammadov 2009, 13-15; Misiagiewicz 2012, 61)

Deste modo, o artigo analisa a presença política e econômica dos Estados Unidos na região do Cáspio durante os governos de George W. Bush (2000-2008) e de Barack Obama (2009-2016), abordando a relação entre o poder estadunidense e os recursos energéticos - com enfoque para os hidrocarbonetos — no contexto da Grande Estratégia; as principais motivações e objetivos dos EUA na região; e, por fim, as semelhanças e diferenças entre os governos de Bush e de Obama para com o Cáspio.

Partimos da ideia de que a relação entre poder e energia na política externa dos EUA é central para a compreensão de todos os desenvolvimentos geopolíticos mundiais e estadunidenses do século passado até a conjuntura atual. Entretanto, não se insere no escopo deste trabalho um estudo exaustivo sobre a correlação destes elementos na política estadunidense. Inúmeras obras discutiram com grande precisão e excelência a temática (Bacevich 2005; Engdahl 1992; Fuser 2005; Klare 2004; Yergin 1991), onde se constata a centralidade do petróleo na política externa dos EUA, além da forte ligação entre o poder - perceptivo e material - estadunidense e o controle — direto ou indireto — dos hidrocarbonetos no mundo.

Entende-se, neste estudo, que o petróleo não pode ser encarado como uma simples mercadoria, e sim como um insumo que contribui para determinar a hierarquia dos Estados no cenário internacional. Principal insumo energético do século XX e, também, do início do século XXI, esse produto insere-se no cenário internacional com base em duas lógicas simultâneas: a econômica e a estratégica (Fuser 2013, 87). 


\section{OS HIDROCARBONETOS E A GRANDE ESTRATÉGIA ESTADUNIDENSE}

O conceito de Grande Estratégia refere-se ao uso de todos os instrumentos de poder disponíveis de um Estado para sua segurança - ou de uma Comunidade de Segurança (Gray 2007, 283; Hooker 2016, 1). Deste modo, cabe ressaltar que ela está um nível acima de estratégias para fins específicos - como a chamada "Guerra ao Terror" ou a segurança energética. A Grande Estratégia enumera e prioriza as ameaças - reais e possíveis - a que o Estado está sujeito. A preservação da soberania estatal, da integridade territorial e da sua posição de poder no cenário internacional são as suas prioridades. Para tal, os Estados que seguem uma Grande Estratégia procuram - simultaneamente - concretizar alianças, prover-se de capacidades militares, econômicas, tecnológicas, de inteligência e, se possível, controlar a ordem internacional (Hooker 2016, 1; Posen 2014 1). O importante historiador estadunidense John Lewis Gaddis, em seu livro "On Grand Strategy" (2018), aprofunda o conceito de Grande Estratégia:

[...] como o alinhamento de aspirações potencialmente ilimitadas com capacidades necessariamente limitadas. Se você busca objetivos além dos seus meios, mais cedo ou mais tarde você terá que reduzir seus objetivos para se ajustar aos seus meios. Meios de expansão podem atingir mais fins, mas nem todos, porque os fins podem ser infinitos e os meios nunca podem ser. Seja qual for o equilíbrio que você atingir, haverá um link entre o que é real e o que é imaginado: entre a sua localização atual e o destino pretendido (2018, 20. Tradução nossa).

Dentro da ótica da Grande Estratégia, os EUA endossaram como grande imperativo de sua segurança — desde o fim da II Guerra Mundial - a proeminência de uma ordem internacional ${ }^{3}$ liberal. Essa ordem foi amplamente caracterizada por uma ênfase nas normas e valores liberais, como o liberalismo econômico na forma de comércio relativamente livre; liberalismo político na forma da difusão democrática além dos direitos humanos e internacional. Essas normas e valores têm se manifestado através de instituições internacionais como o Fundo Monetário Internacional (FMI), Banco Mundial (BM), Organização Mundial do Comércio (OMC), Organização das Nações Unidas (ONU), União Europeia (UE) e, inclusive, a Organização do Tratado do Atlântico Norte (OTAN) (Brands 2016, 1-3). Nesse arcabouço institucional, os Estados Unidos, fundamentados pelo ordenamento liberal, têm sido um império informal baseado em espalhar sua influência econômica assegurando o livre acesso a bens vitais 
e matérias-primas, inclusive estabelecendo presença militar em áreas de interesse, em prol do status quo (Mahdi 2010, s.p.).

Especificamente sobre os recursos energéticos, pode-se dizer que, desde os Choques do Petróleo na década de 1970, a relação entre a política externa estadunidense e seus interesses petrolíferos se tornou notória. Os EUA responderam com extraordinária consistência aos desafios impostos pela geopolítica mundial do petróleo, procurando sistematicamente expandir seu domínio sobre ela, tanto nos períodos do aumento vertiginoso dos preços, entre 2001 e 2008, quanto no cenário posterior ao colapso dos preços em 1998 (Lehmann 2017, 118). Com o fim da Guerra Fria, a estratégia estadunidense de segurança internacional passou a priorizar, ainda mais, sua segurança econômica para a manutenção da hegemonia ${ }^{4}$ (Klare 2001, 7; Yergin 1991, 768). A partir desta conjuntura é que a atual estratégia prepositiva — de segurança energética dos EUA, iniciada com a Doutrina Carter, adquiriu solidez e passou a ser aplicada vigorosamente.

Assim, o acesso e o controle sobre o suprimento global de petróleo representam um fator para a manutenção da ordem liberal e, consequentemente, da hegemonia estadunidense. Esta abordagem tem sido particularmente evidente nas regiões produtoras de energia, onde os EUA visam estabelecer o domínio político-econômico — se necessário, militar — para endossar o seu poder econômico global. Portanto, com o intuito de sustentar a economia americana e as suas forças armadas, os EUA buscam incessantemente o acesso irrestrito a grandes volumes de petróleo. Ademais, como hegemon, os Estados Unidos foram responsáveis pela estabilidade contínua da economia internacional liberal e o fornecimento de segurança "global”. Neste sentido, o fluxo ininterrupto de recursos energéticos é fundamental para assegurar a ordem internacional liberal. Ademais, o domínio - direto ou indireto - da geopolítica energética pelos EUA também garante que os Estados rivais - reais e possíveis - sejam incapazes de ter acesso às quantidades de hidrocarbonetos necessárias para desafiar - militarmente e economicamente - a hegemonia dos EUA (Chomsky 2003, 16 e 123; Mahdi 2010, s.p.; Morris 2015, 77-9;). A proteção das áreas de exploração e das rotas comerciais dos recursos vitais para economia, como petróleo e gás, se tornou um tópico de extrema prioridade na agenda internacional. 


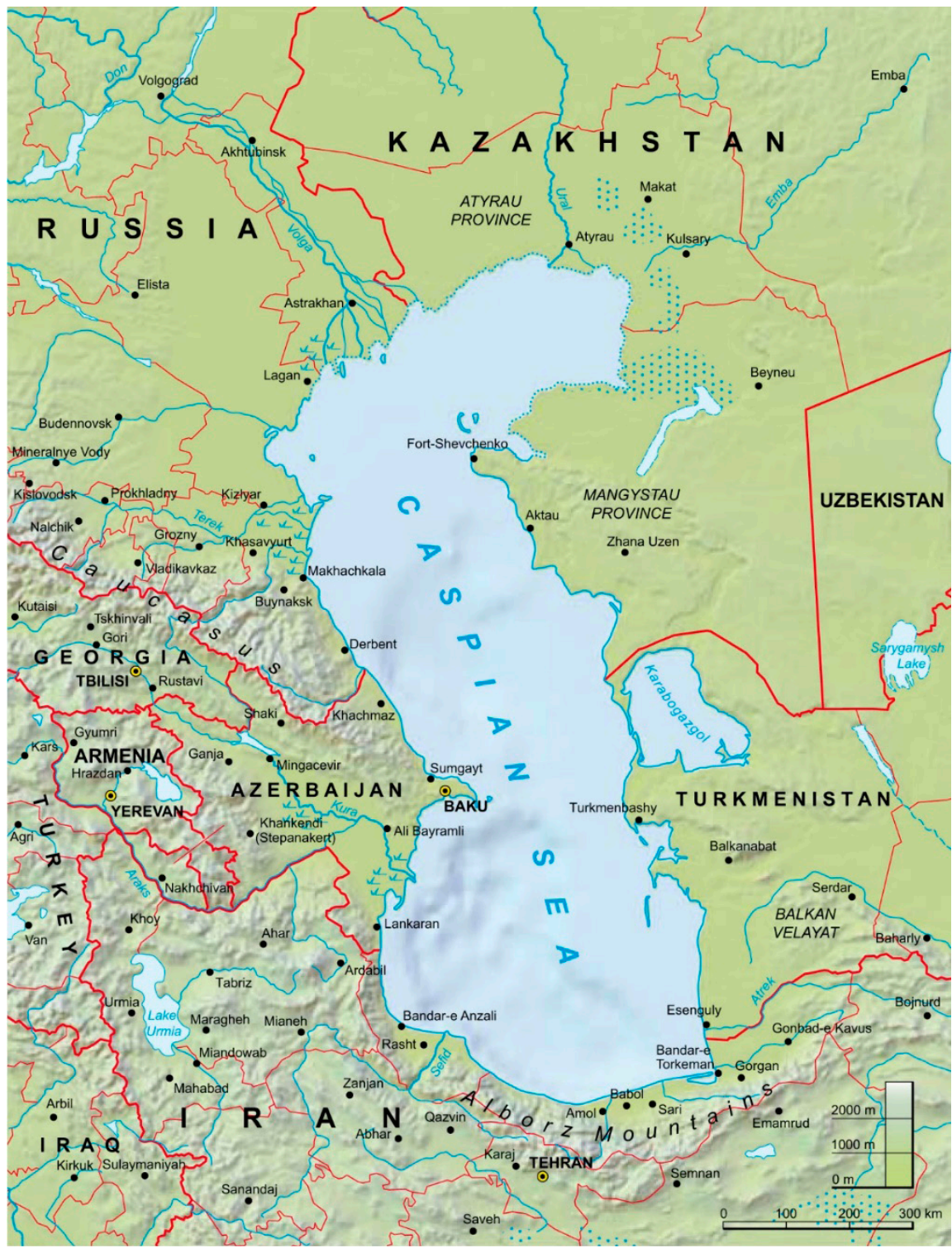

Mapa 1 - Político e Topográfico da Região do Cáspio.

Fonte: UNEP (2008). 
A partir deste arcabouço estratégico é que os interesses estadunidenses se inserem na região do Cáspio. Afinal, quantidades muito pequenas de hidrocarbonetos produzidas no Cáspio chegam ao mercado estadunidense. Em vez disso, os interesses de Washington " $[\ldots]$ no Mar Cáspio e Ásia Central podem ser descritos como mais políticos do que econômicos” (Benke 2010, 28, tradução nossa) sendo eles: assegurar que os hidrocarbonetos do Cáspio ingressem no mercado global (em vez de serem monopolizados através de acordos bilaterais com a China ou a Rússia) e garantir que o petróleo e o gás da região possam ser usados para minar a posição dominante da Rússia no abastecimento energético europeu - uma vulnerabilidade geopolítica capital de que os tomadores de decisão norte-americanos estão todos muito conscientes. Assim, a redução da grande dependência energética europeia do fornecimento russo tornou-se um objetivo primordial para Washington, que tenta resolver esse problema através da promoção da diversificação das rotas de transporte de energia para a Europa (Stokes and Raphael 2014, 8-13).

O valor geoestratégico da Região do Cáspio para os Estados Unidos não se restringe unicamente às questões de segurança energética, mas também apresenta implicações para a "Grande Estratégia” dos EUA do século XXI. A este respeito, os EUA não só visam a controlar setores energéticos regionais, mas também a competir com os potenciais adversários geopolíticos à sua "Grande Estratégia", como a China e a Rússia (Misiagiewicz 2012, 64-5). Neste sentido, o ex-assessor de Segurança Nacional dos EUA, Zbigniew Brzezinski, em seu livro The Grand Chessboard (1997), denominou o núcleo da região que hoje, usualmente, é chamada de Região do Cáspio de "Balcãs Eurasiáticos". Brzezinski justifica a denominação pela similaridade com a região europeia, quer seja pela sua importância estratégica, bem como por causa da região ser — como ele mesmo denomina — um “caldeirão étnico". De tal modo, Brzezinski compreende a centralidade da região nas relações internacionais, quer seja pela rede de transportes, inevitavelmente, emergente destinada a ligar as duas extremidades mais ricas do continente eurasiano - Europa e Ásia Oriental, quer pelas questões de segurança internacional e de ambições históricas das potências próximas - Rússia, Turquia, Irã e China. Entretanto, para o ex-assessor, os Balcãs Eurasiáticos são infinitamente mais importantes que seu homônimo europeu, por deterem uma enorme concentração de petróleo e gás natural (Brzezinski 1997, 123-5).

O objetivo estratégico fundamental de Washington tem-se pautado, ao longo do período pós-Guerra Fria, na criação de parceiros estáveis, seguros, democráticos e prósperos que apoiam a concorrência do livre mercado (Stokes and Raphael 2014, 9). Dentro desta lógica, entende-se que os 
Estados Unidos estão interessados em garantir que a Rússia (ou China) não se eleve como uma potência hegemônica no coração da Eurásia. Para este fim, os EUA tentam cooptar as ex-repúblicas soviéticas da esfera de influência russa, incentivando movimentos democráticos pró-ocidentais e pró-estadunidenses, e apoiando as chamadas "Revoluções Coloridas" (Benke 2010, 28). Juntamente com o impulso para a reforma econômica e democrática no Cáspio, Washington tem procurado estabilizar os regimes beneficiários através da provisão de programas de assistência de segurança para os militares da região. Isso se encaixa como um tema de longa data no pensamento estratégico americano: a prestação do financiamento, armamento e treinamento para as forças de segurança aliadas em regiões-chave de todo o mundo, a fim de estabilizar áreas importantes e garantir que permaneçam no interior da órbita dos Estados Unidos de influência e ligadas à economia global (Stokes and Raphael 2014, 10). Como indicam os pesquisadores Stronski, Rumer, and Sokolsky $(2016,17)$, entre 1992 e 2014 os recursos provenientes de assistência econômica e/ou militar dos EUA para os países da Ásia Central totalizaram cerca de 6,8 bilhões de dólares (em valores de 2016). De modo geral, a política dos EUA na região do Cáspio é parte de sua estratégia global para tornarem-se a única superpotência mundial do século XXI (Abilov 2012, 37),

“[...] controlar o acesso as reservas de petróleo globais garantem poder relativo de Washington vis-à-vis potenciais e reais rivais. Essa lógica pode ser vista talvez de forma mais clara em relação ao poder emergente chinês. (...). É neste contexto que o domínio político e militar de Washington sobre as políticas econômicas dos Estados ricos em petróleo gera enorme poder estrutural para o Estado americano. Dado que, qualquer concorrente sério à primazia dos EUA exigiria acesso irrestrito as vastas quantidades de petróleo, e que a prevenção do surgimento de qualquer desses desafios é um tema central da estratégia dos EUA, controlar o acesso a essa commodity tem sido um objetivo basilar" (Stokes and Raphael 2014, 7, tradução nossa).

\section{Governo Bush: o engajamento no coração da Eurásia}

Ao assumir a presidência em 2001, a primeira prioridade da política externa de George W. Bush não foi a "guerra ao terror" e a expansão da democracia estadunidense - estes objetivos só ganharam o impacto atual após os atentados de 11 de setembro de $2001-$, mas sim a de aumentar os fluxos de recursos energéticos para os EUA (Klare 2004, 56), devido às sistemáticas crises energéticas que assolavam o país pouco antes de assumir a presidência. Outro fator, não menos importante, foi que em 1998 - pela primeira vez na história - o petróleo importado passou a corresponder a 
mais de 50\% de todo o consumo nacional. Deste modo, Spencer Abraham, secretário da Energia do governo Bush, demonstrou sua preocupação em março de 2001: "A América enfrentará a maior crise de abastecimento de energia nas próximas duas décadas. A incapacidade de responder a este desafio irá ameaçar a prosperidade econômica da nossa nação, comprometer a nossa segurança nacional” (tradução nossa).

A inquietação perante a grande dependência de petróleo importado por parte dos EUA foi tema ao longo de todo o governo de Bush. Como pode ser observado no gráfico que se segue, de 2001 a 2006 as quantidades de petróleo importado aumentavam ano a ano. Ademais, em relatório da Energy Information Agency de 2005, estimava-se que as importações totais de petróleo dos EUA aumentariam de 12,3Mb/d (milhões de barris diários) para $20,2 \mathrm{Mb} / \mathrm{d}$ até 2025 (EIA 2005, 74). Neste sentido, o renomado analista de economia política da energia Daniel Yergin alertava em 2006 que os desafios da segurança energética estadunidense se tornariam ainda mais estarrecedores, tornando fundamental aos EUA assegurarem a segurança dos mercados globais. Para tal, os EUA deveriam fomentar a coordenação tanto nacional como internacionalmente, incluindo as empresas, governos, organismos internacionais, e as forças armadas e de inteligência (Yergin 2006).

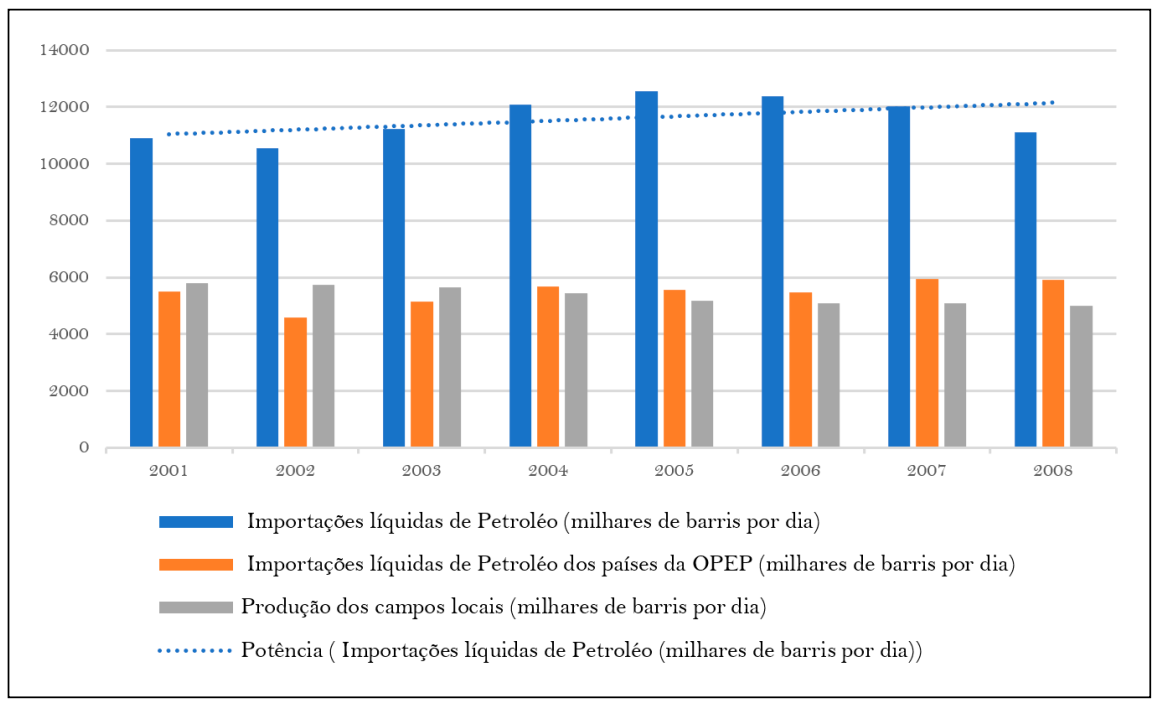

Gráfico 1 - Produção e importação de petróleo pelos EUA (2001-2008).

Fonte: Elaborado pelos autores com dados da BP (2017). 
Dada tal conjuntura, George W. Bush assumiu a resolução da crise energética estadunidense como sua maior prioridade. Na sua administração, a gravidade do petróleo na manutenção da hegemonia estadunidense, e a importância da parceria público-privada no setor petroleiro, atingiram um novo patamar. Bush trouxe o petróleo à tona na formulação de sua política externa, elevando o lugar da obtenção de recursos energéticos a um nível nunca visto. Bush apresentou o petróleo como parte de uma nova abordagem estratégica, evidenciada na formulação da National Energy Policy.

Para responder à crise energética, Bush criou uma força tarefa intitulada de National Energy Policy Development Group(NEPDG), que teria como objetivo criar uma estratégia capaz de atender às necessidades energéticas dos EUA. Nesse sentido, nomeou como coordenador do NEPDG, o seu vice-presidente, Richard Cheney, que - assim como Bush - tinha laços com a indústria petrolífera, ${ }^{5}$ na condição de presidente e diretor-geral da Halliburton.

A partir do relatório final do NEPDG, constou-se que para a resolução da crise energética estadunidense havia dois caminhos - opostos - a serem seguidos. O primeiro seria uma via mais difícil - que implicaria na necessidade de alterar a própria estrutura da economia norte-americana - orientada para um programa voltado à utilização de energias renováveis a fim de reduzir progressivamente a dependência do petróleo em todo o mercado estadunidense. Já a segunda via optava pela continuidade do grande consumo petrolífero, com o foco na maximização da diversidade de fornecedores e na segurança do mercado global de energia - assumindo, assim, a dependência do petróleo externo. George W. Bush optou em favor da continuidade do petróleo como base da matriz energética estadunidense e, consequentemente, do aumento da dependência nas importações petrolíferas. (Klare 2004, 61-3; Mahdi 2010, 17-8; Sébille-Lopez 2006, 68-9).

Através do exame do relatório, no oitavo capítulo do NEP — denominado, Strengthening Global Alliances - é possível observar as verdadeiras intenções do governo Bush, em relação a assegurar o fluxo dos recursos energéticos provenientes do exterior. Logo no início do capítulo, já é crível a preocupação com o mercado mundial de energia:

A segurança energética nacional dos EUA depende do fornecimento de energia suficiente para apoiar os Estados Unidos e um crescimento econômico global. As políticas energéticas que têm enfatizado confiança nas forças de mercado levaram a importantes ganhos de segurança energética nas últimas duas décadas. As principais melhorias em exploração e tecnologia de produção, bem como a tendência 
para a abertura de novas áreas ao redor do mundo para a exploração e desenvolvimento (National Energy Policy 2001, 1. Tradução nossa).

A seguir o documento relata que a segurança energética dos EUA não pode ser vista de maneira isolada do resto do mundo. "Em um mercado global de energia, a segurança energética e econômica dos Estados Unidos está diretamente ligada não só para os nossos suprimentos nacionais e internacionais, mas também para aqueles de nossos parceiros comerciais" (National Energy Policy 2001, 1, tradução nossa). De acordo com esse documento, qualquer desequilíbrio no mercado mundial de petróleo pode afetar não só a economia estadunidense como também a própria capacidade de promover os principais objetivos dos EUA, tanto econômicos quanto externos, independentemente do nível de dependência do país perante os insumos energéticos importados. Assim, a NEP preconizava que os EUA devem apoiar uma duradoura política de liberalização do mercado energético mundial para sempre estar aberto para ao comércio e investimento internacional. Afinal, a concentração da produção petrolífera mundial em uma só região do globo é potencialmente causadora da instabilidade do mercado — vide os Choques do Petróleo na década de 1970 (National Energy Policy 2001, 6).

Deste modo, nas linhas da manutenção da ordem liberal, o documento afirma que o fortalecimento da segurança energética estadunidense também possibilita a prosperidade da economia global através da cooperação dos principais países produtores e instituições em prol da expansão da produção energética mundial. $\mathrm{O}$ texto também alerta para a necessidade de "fortalecer nossas alianças comerciais, para aprofundar nosso diálogo com os principais produtores de petróleo e para trabalhar em prol de uma maior produção de petróleo no Hemisfério Ocidental, África, do Mar Cáspio e de outras regiões com recursos petrolíferos abundantes" (National Energy Policy 2001, 3, tradução nossa).

Assim, o papel central dos recursos energéticos, na administração de George W. Bush e Richard Cheney, estava inerentemente ligado a outros objetivos da política externa estadunidense. Tal como a hegemonia dos EUA e o seu avanço militar, que foram alguns dos principais objetivos, controlar a geopolítica mundial do gás e petróleo foi prioridade primária da política externa de Washington - embora não declarada. Portanto, tornou-se cada vez mais claro que não só a invasão do Iraque, mas também a incursão no Afeganistão, não eram meramente compromissadas com a expansão da democracia e, na realidade, foram utilizadas como justificativa para o controle dos gasodutos em toda a Ásia Central e a ocupação militar do Oriente Médio, de acordo com uma estratégia geral voltada para 
o avanço dos interesses energéticos dos EUA (Enghdal 2009, 53; Mahdi 2010, 17-8). "Devido à posição da energia na busca/perseguição pelo poder, certos casos tornaram-se centrais na abordagem de Bush (principalmente o Iraque), atuando como o que eu chamo de pontos de interseção onde todos esses objetivos foram feitos para serem alcançados" (Mahdi 2010, 18, tradução nossa, grifo do autor).

Além disso, após os ataques de 11 de setembro e da invasão do Afeganistão, estabeleceu-se a Doutrina Bush, que possuía quatro focos de política externa: aquisição de energia; avanço militar; antiterrorismo; e projeção de poder global (Mahdi 2010, 22). O polêmico pesquisador William Engdahl compreende que o governo de Bush e Dick Cheney se baseou na concepção de que a política externa estadunidense deveria ter como objetivo primário garantir o que o Pentágono denomina de "Full Spectrum Dominance" ${ }^{6}$ De acordo com essa ideia, o controle dos recursos energéticos era essencial na estratégia de poder global estadunidense. Portanto, a administração Bush implementou o consenso de que eram necessárias drásticas mudanças na política externa dos EUA - uma postura extremamente agressiva, adotada com o objetivo de alcançar o controle das reservas de petróleo mundial - a fim de que os EUA continuassem a controlar o crescimento da economia mundial e, também, de prevenir o surgimento de potências rivais. "Ficou claro nos círculos políticos de Washington que, a fim de controlar esses fluxos de petróleo e gás, os Estados Unidos precisavam projetar seu poder militar muito mais agressivamente, para alcançar uma supremacia militar total” (Enghdal 2009, 55, tradução nossa).

Neste cenário, a região do Cáspio passa a ser pauta importante da política externa estadunidense, quer seja por suas potencialidades energéticas como também para a contenção de seus adversários geopolíticos - Irã e Rússia. Em 2005, na Geórgia, o presidente George Bush — em total consonância com o ordenamento liberal — proferiu a seguinte frase: "Agora, no Cáucaso, na Ásia Central e no Oriente Médio, vemos o mesmo desejo de liberdade queimando no coração dos jovens. Eles estão exigindo sua liberdade - e eles a terão.” (Bush 2005, tradução nossa)

Ademais, a região do Cáspio está presente na NEP — principalmente no que tange à temática da diversificação da oferta. O relatório avalia, ainda, que os investimentos estrangeiros e a alta tecnologia são fatores críticos para o rápido desenvolvimento das novas rotas de exportação economicamente viáveis. Este desenvolvimento iria, consequentemente, garantir que o aumento da produção petrolífera do Mar Cáspio fosse integrado, de fato, ao comércio mundial do petróleo. Para isso, os EUA deveriam apoiar a construção das novas rotas de oleodutos que iriam adicionar nova capacidade de transporte, permitindo a inserção de uma fatia energética subs- 
tancial ao mercado mundial. Dentre as recomendações do NEPDG para o presidente George W. Bush que são referentes ao Cáspio estavam:

- fazer da segurança energética uma prioridade das políticas econômicas e externas dos EUA;

- apoiar o oleoduto Baku-Tbilisi-Ceyhan (BTC), assim como demonstrar sua viabilidade comercial;

- trabalhar em conjunto com empresas e países relevantes para o estabelecimento de condições comerciais que permitirão que as empresas petrolíferas que operam no Cazaquistão possam exportar seu petróleo através do oleoduto BTC;

- apoiar os esforços dos investidores privados e dos governantes regionais para o desenvolvimento do gasoduto Shan Deniz, como uma forma de ajudar Turquia e Geórgia na diversificação de seus suprimentos de gás, e também para ajudar nas exportações de gás do Azerbaijão por meio dos gasodutos que irão fomentar a diversificação das rotas seguras de suprimentos energéticos;

- encorajar Grécia e Turquia para conectar seus sistemas de gasodutos para possibilitar aos consumidores europeus maior diversificação de seus suprimentos de gás provenientes da Bacia do Cáspio; e

- aprofundar os diálogos comerciais com Cazaquistão, Azerbaijão e outros Estados do Cáspio para proporcionar um ambiente de negócios forte, transparente e estável para a energia e projetos de infraestrutura relacionados.

\section{A REGIÃO DO CÁSPIO NO CONTEXTO DA DOUTRINA CARTER}

Em relação à sua estratégia militar, diante da constante ameaça de instabilidade de seus fornecedores de petróleo, os Estados Unidos têm respondido, previsivelmente, através da elevação de sua capacidade militar. Neste sentido, esta resposta representa uma extensão da Doutrina Carter para novas áreas do mundo. Pela primeira vez na história dos EUA se observou um discurso tão enfático em relação à proteção e emprego do uso da força para proteger o fluxo contínuo de petróleo. O livre acesso para o petróleo do Golfo Pérsico era vital para os interesses norte-americanos e nos meses seguintes ao discurso de Carter, os EUA começaram sua escalada militar no Golfo Pérsico. Jimmy Carter promulgou uma série de medidas para facilitar a projeção estadunidense no Pérsico (Klare 2004, 33). Como símbolo da Doutrina Carter, o U.S. Central Command, originalmente criado para proteger o Golfo Pérsico, agora possui autoridade sobre os Estados da Ásia Central na bacia do Cáspio, desde 1999 (Klare 2004, 132). 
Em suma,

[n]a medida em que os interesses dos EUA no petróleo da região estão entrelaçados com uma posição mais ampla de Washington como hegemon global, portanto, os planejadores norte-americanos permanecem alertas para os potenciais desafios do poder chinês e russo ao mesmo tempo, desejando um futuro onde os estados-chave - incluindo China e Rússia - estão mais integrados para a ordem mundial liderada pelos EUA. Neste sentido, as contas de um retorno à rivalidade inter-imperialista na Bacia do Cáspio não estimam plenamente o grau em que o poder hegemónico global continua comprometido com uma ordem mundial baseada em uma grande parte na soma-positiva, no regime de comércio de portas abertas, incluindo o setor energético. Estratégias de cobertura por Washington contra a ascensão de competidores aliados devem ser lidas juntamente com as contínuas tentativas de amenizar conflitos futuros através da sua pacificação e integração na ordem liberal liderada pelos Estados Unidos" (Stokes and Raphael 2014, 16-17. Tradução nossa).

Consequentemente, a partir de 2002 os Estados Unidos puderam lançar amplos programas de cooperação militar com o Azerbaijão e intensificar seus laços já existentes com o Cazaquistão e o Turcomenistão, fornecendo aos Estados litorâneos do Cáspio uma quantidade considerável de dólares para ajuda militar, principalmente sob os programas Foreign Military Financing, Counterterrorism Fellowship Program e do International Military Education and Training (ver Tabela 1) (Frappi 2013, 193).

\section{Tabela 1}

Orçamento anual dos EUA para fundos de segurança para os Estados litorâneos do Cáspio (em milhões de dólares — 2013)

\begin{tabular}{lrr|r|r|r|rrr|} 
& $\mathbf{2 0 0 2}$ & $\mathbf{2 0 0 3}$ & $\mathbf{2 0 0 4}$ & $\mathbf{2 0 0 5}$ & $\mathbf{2 0 0 6}$ & $\mathbf{2 0 0 7}$ & $\mathbf{2 0 0 8}$ & $\mathbf{2 0 0 2 - 2 0 0 8}$ \\
\hline Azerbaijan & 14.82 & 10.79 & 18.47 & 33.14 & 33.02 & 33.56 & 47.41 & 191.21 \\
Kazakhstan & 17.32 & 28.71 & 52.55 & 42.34 & 19.35 & 60.64 & 60.39 & 281.30 \\
Turkmenistan & 5.93 & 0.96 & 2.70 & 6.58 & 1.75 & 5.27 & 5.37 & 28.56 \\
\hline
\end{tabular}

Fonte: Frappi (2013).

Como observado na tabela acima, ocorreram aumentos significativos dos níveis de assistência militar estadunidense na região do Cáspio. Além disso, após o 11 de setembro, as relações de segurança dos EUA com os Estados da região do Cáspio passaram por uma mudança radical. Stokes e Raphael $(2014,11)$ compreendem que os programas estadunidenses de 
assistência militar na região têm sido focalizados nos Estados ricos em petróleo ou estratégicos para o escoamento da produção, com o desejo declarado de garantir o fluxo ininterrupto dos recursos do Cáspio para o mercado mundial. "Há uma dimensão de segurança energética clara em jogo aqui. Historicamente, os Estados Unidos forneceram assistência de modo a criar estruturas de comando dedicados à segurança energética" (Stokes and Raphael 2014, 11, tradução nossa).

Neste sentido, pode-se dizer que os programas de assistência fornecidos ao Cazaquistão tinham, explicitamente, como objetivo equipar e treinar as forças militares cazaques para proteger infraestrutura de energia do Cáspio e as principais rotas de transporte de energia. Da mesma forma, a assistência militar para o Azerbaijão tem sido orientada em prol da estabilização do regime Aliyev $^{7}$ e da garantia do fluxo constante de petróleo e gás ao mercado mundial. Juntamente com a estabilização dos dois principais Estados produtores de petróleo do Cáspio, os Estados Unidos tomaram medidas para assegurar que o Estado de trânsito da Geórgia — onde está localizado o oleoduto Baku-Tbilisi-Ceyhan - esteja seguro contra os focos de instabilidade interna (Stokes and Raphael 2014, 11-2). "Em geral, os comandantes militares norte-americanos estão claros de que a maximização da segurança energética global é um objetivo-chave para Washington, e que os programas de assistência à segurança desempenham um papel central neste processo" (Stokes and Raphael 2014, 13, tradução nossa).

Fora do campo da segurança regional e militar, o grande destaque da atuação estadunidense no Cáspio ao longo do governo Bush foi, sem dúvida, a consolidação do oleoduto Baku-Tbilisi-Ceyhan (BTC), iniciado na década de 1990. Além disso, pode-se dizer que o BTC foi o maior - e mais estratégico - projeto que os EUA fomentaram em todo o espaço pós-soviético. A importância estratégica do BTC está relacionada ao fato de conectar diretamente os campos de petróleo do Cáspio - sem acesso aos oceanos - ao mercado global, sem transcorrer os territórios russo e iraniano. Desse modo, recursos do Cáspio que antes fluíam apenas para os portos russos no Mar Negro passaram a ser direcionados também para o porto turco de Ceyhan, com maior acessibilidade ao mercado global sem a necessidade de perpassar pelos estreitos de Bósforo e Dardanelos afetando diretamente as ambições de longo prazo da Rússia. (Cornell, Tsereteli, and Socor 2005, 22-3 e 30)

A primeira etapa do oleoduto Baku-Tbilisi-Ceyhan (BTC) foi oficialmente inaugurada em 25 de maio de 2005 no terminal marítimo de Sangachal, ao sul da capital do Azerbaijão, Baku. Estiveram presentes para a inauguração os presidentes da Turquia, Azerbaijão, Geórgia e Cazaquistão, bem como o presidente da BP, o secretário de Energia dos EUA, o emissário do 
Departamento de Estado dos EUA para o Cáucaso do Sul e o comissário de Energia da União Europeia. O oleoduto Baku-Tbilisi-Ceyhan (BTC) transporta petróleo proveniente do Azerbaijão, Cazaquistão e, em menores quantidades, do Turcomenistão. A linha vai do terminal de Sangachal (Sul de Baku, Azerbaijão) até Ceyhan (Turquia), detendo uma extensão total de 1.760 quilômetros, incluindo 445 quilômetros no Azerbaijão, 245 na Geórgia e 1.070 na Turquia. Ademais, o throughput do oleoduto era de um milhão de barris por dia entre 2006 e 2009. A partir de março de 2009, sua capacidade se elevou para 1,2 milhão de barris por dia através da utilização de polímeros redutores de arrasto (DRP's, na sigla em inglês) (BP 2018; Socor 2005)

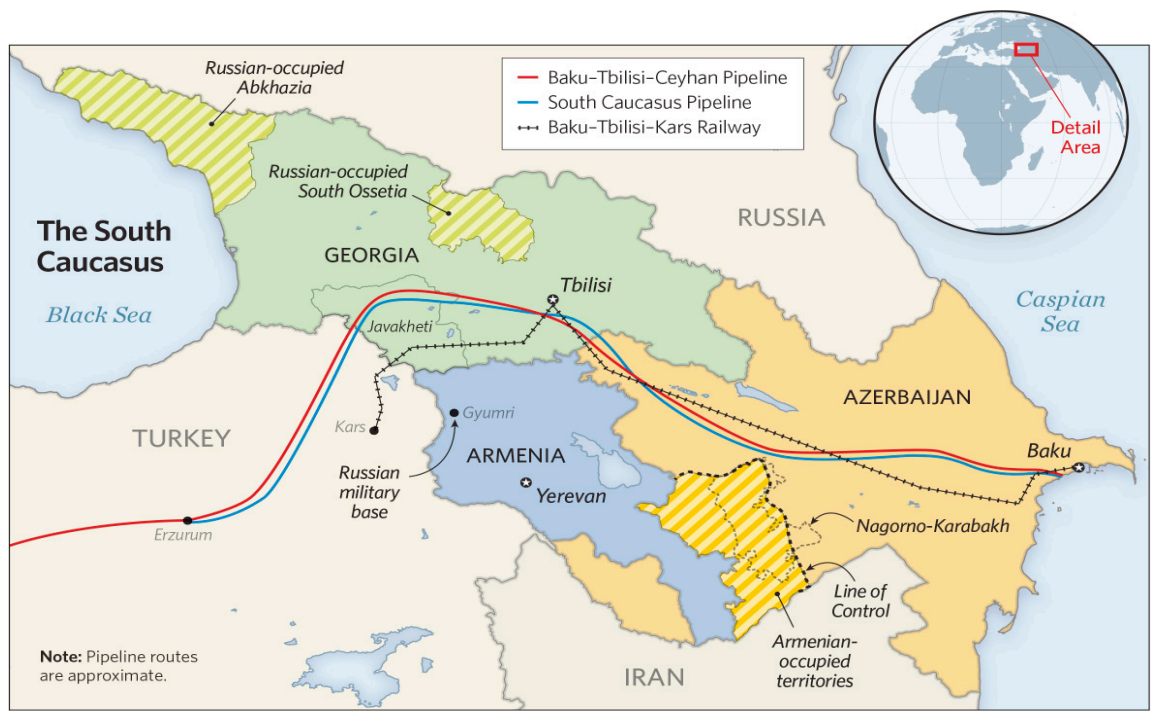

Mapa 2 - Oleoduto Baku-Tbilisi-Ceyhan (BTC).

Fonte: Heritage (2016).

Para a realização do projeto, foi formalizada uma joint-venture composta por diversas empresas do setor petrolífero, sendo elas: BP, detendo 30,1\% das ações; AzBTC (Azerbaijão), com 25\%; Chevron (EUA), 8,9\%; Equinor (Noruega), 8,71\%; TPAO (Turquia), 6,53\%; ENI (Itália), 5\%; Total (França), 5\%; Itochu (Japão), 3,40\%; Inpex (Japão), 2,5\%; ExxonMobil (EUA), 2,5\%; e, ONGC (Índia), 2,36\%. (BP 2018) Entretanto, o projeto só foi efetivado devido ao grande apoio de bancos governamentais dos EUA e do Japão, do Banco Mundial e do Banco Europeu de Reconstrução e Desenvolvimento, que for- 
neceram créditos cobrindo cerca de 70\% dos custos da construção. Os membros supracitados do consórcio BTC cobriram 30\% dos custos. Inicialmente orçado em 2,9 bilhões de dólares, custou 4 bilhões de dólares. (Socor 2005).

Devido aos custos exorbitantes, pode-se dizer que o BTC não possui sentido em termos de racionalidade econômica. Como aponta o analista geopolítico Pepe Escobar, há consciência entre os especialistas do setor petrolífero de que eventuais rotas direcionadas ao Sul — através do Irã — seriam menos custosas. Todavia, o analista destaca que o BTC é considerado uma "obra-prima" da política de poder - na perspectiva do Ocidente. Em suas próprias palavras: "Em termos de política de poder (sem escrúpulos) e geopolítica do petróleo, o BTC é um componente-chave na estratégia geral dos EUA de lutar contra o Cáucaso e a Ásia Central longe da Rússia e contornar as rotas de petróleo e gás iranianas” (Escobar 2005, tradução nossa).

De modo geral,

O fato de que o projeto Baku-Ceyhan é essencialmente, do ponto de vista de Washington, uma questão de importância geoestratégica e política primordial e não econômica, ilustra e até sintetiza que as políticas de Washington na região priorizam a segurança político-militar a fim de assegurar a estabilidade da região (Oktav 2005, 31. Tradução nossa).

Apesar do grande sucesso estratégico do BTC, os EUA não tiveram o mesmo sucesso com os projetos relacionados ao gás - principalmente provenientes do Turcomenistão. A concepção de um duto submarino através do Cáspio (Trans-Cáspio, TCP) seria o próximo passo para o desenvolvimento do corredor dutoviário Leste-Oeste e, consequentemente, da estratégia ocidental para redução da dependência Europeia em relação ao gás russo. Entretanto, por diversos impeditivos tais como o status legal do Cáspio e dificuldade na capitalização de recursos para a construção do duto, o projeto não saiu dos gabinetes do alto comando estadunidense (Cornell, Tsereteli, and Socor 2005, 31; Khalifazadeh 2014, 88).

Por fim, cabe ressaltar que, ao longo dos oito anos de governo de George W. Bush, as relações diplomáticas com a Rússia pioraram vertiginosamente, a ponto de, no final de seu mandato, analistas de política internacional endossarem a ocorrência de uma "Nova Guerra Fria". Esta deterioração nas relações está atrelada a inúmeros eventos, entre os quais o alargamento da OTAN no espaço pós-soviético, a proposta da criação do escudo antimísseis no leste da Europa e as Revoluções Coloridas. Esse processo de aumentos das tensões geopolíticas entre Washington e Moscou teve como episódio mais crítico a Guerra Russo-Georgiana em 2008. 


\section{OBAMA E A RETIRADA DO “NOVO GRANDE JOGO”}

Após Barack Obama assumir a presidência dos EUA em 2009, o engajamento estadunidense na região do Cáspio se reduziu de modo significativo. Em primeiro lugar, isso se deve às mudanças profundas na conjuntura energética estadunidense ocasionadas pela chamada "Revolução do Xisto", ou seja, pelo aumento vertiginoso de produção de petróleo e de gás natural (examinar o processo através do Gráfico 2 ) pelo método inovador do fracionamento hidráulico, conhecido como fracking. Em segundo lugar, pode-se dizer que ocorreram mudanças significativas no eixo da política externa estadunidense com a ênfase inicial — antes dos episódios da Crimeia/Ucrânia em 2014 - no restabelecimento das relações com a Rússia - conhecido como reset das Relações EUA-Rússia - e, também, com a estratégia do "Pivô para a Ásia-Pacífico". Por fim, o processo de retirada das tropas estadunidenses no Afeganistão e o considerável desengajamento militar dos assuntos referentes ao Grande Oriente Médio (que inclui o Cáspio).

Neste sentido, o pesquisador-sênior do Atlantic Council, ${ }^{9}$ Ariel Cohen, em testemunho perante à Subcomissão Europa e Eurásia, do Comitê de Relações Internacionais do Congresso dos EUA em 2012, afirmou:

Infelizmente, o governo Obama negligenciou o espaço pós-soviético em geral e o coração da massa terrestre da Eurásia em particular. Durante meses e anos, as principais embaixadas no Turcomenistão e no Azerbaijão continuaram sem serem preenchidas. Não houve uma estratégia coerente para a Eurásia articulada pela Casa Branca (Tradução nossa).

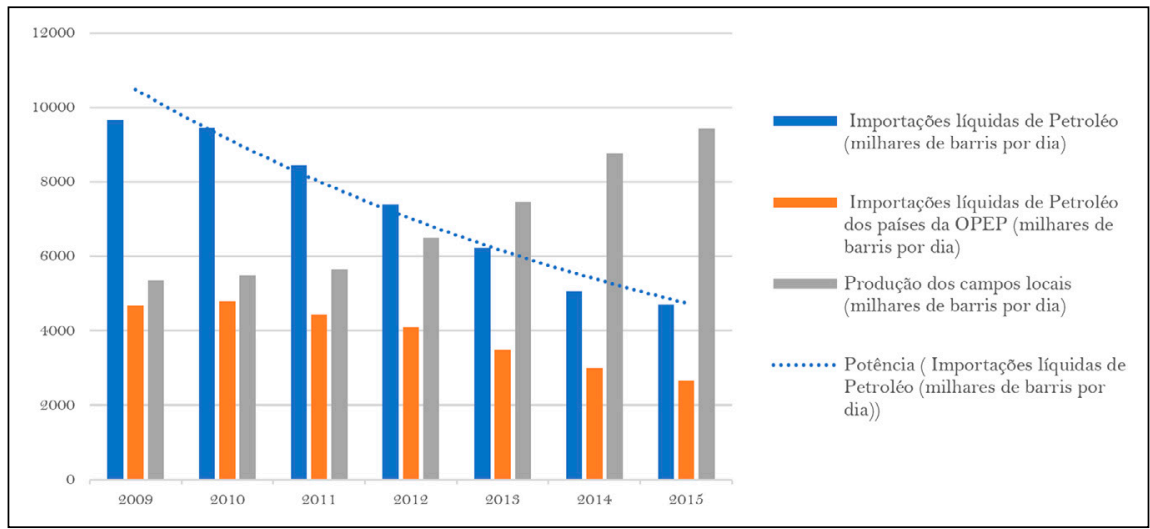

Gráfico 2 - Importações vs. Produção de Petróleo nos EUA 2009-2015. Fonte: elaborado pelo autor com dados da British Petroleum (2017). 
Primeiramente, quando Barack Obama assumiu a presidência, as relações entre os Estados Unidos e a Rússia estavam — até então - no ápice de seu antagonismo pós-Guerra-Fria. Deste modo, foi anunciada, quase de imediato, uma nova estratégia de política externa em relação à Rússia, denominada "reset", com o objetivo de substituir os inúmeros conflitos pela cooperação. Incorporado ao "reset”, os EUA, por exemplo, postergaram o processo de adesão de novos membros à OTAN — como Ucrânia e Geórgia - e, em contrapartida, receberam apoio (momentâneo) da Rússia em alguns objetivos-chave da política externa estadunidense, como o confronto com o Irã — nas questões relativas ao desenvolvimento de energia nuclear - e o Afeganistão — suporte de logística e inteligência. Naturalmente, para a consumação do plano de Obama, seria necessário um desengajamento estadunidense no "Exterior Próximo" russo - que, de fato, ocorreu (Garashova 2014, 30-1; Khalifazadeh 2014, 81-7). Como aponta a pesquisadora azeri Sabina Garashova, “[m] uitos especialistas ocidentais compreendem que os EUA se afastaram essencialmente do problema dos conflitos (congelados) no Cáucaso do Sul e, ao fazê-lo, renderam sua posição à Rússia” (2014, 31, tradução nossa). Conforme as interpretações de Stephen Blank (2014, 170-1) e Ariel Cohen (2012), a ausência dos EUA nos assuntos do Cáspio deu grande margem de manobra para a Rússia reafirmar-se em seu Exterior Próximo.

Michael Klare (2011) e Nikolas Gvosdev (2013) compreendem que os EUA concentrariam seu poder na região do Ásia-Pacífico em detrimento do "Grande Oriente Médio" - conceito geográfico que inclui o Cáspio. Assim, Klare (2011) e Gvosdev (2013) acreditavam que os EUA passaram a pôr em prática uma política de contenção à China no Pacífico. As observações dos autores podem ser comprovadas pelo discurso de Obama proferido ao Parlamento australiano em 17 de novembro de 2011. Nas palavras do então presidente dos EUA:

Para os Estados Unidos, isso reflete uma mudança mais ampla. Depois de uma década em que lutamos duas guerras que nos custaram muito, em sangue e tesouros, os Estados Unidos estão voltando nossa atenção para o vasto potencial da região Ásia-Pacífico [...]. Minha orientação é clara. À medida que planejamos e orçamos para o futuro, alocaremos os recursos necessários para manter nossa forte presença militar nessa região. Nós preservaremos nossa capacidade única de projetar poder e deter ameaças à paz [...]. E fortaleceremos constantemente nossas capacidades para atender às necessidades do século XXI. Nossos interesses duradouros na região exigem nossa presença duradoura na região. Os Estados Unidos são uma potência do Pacífico e estamos aqui para ficar (Tradução nossa). 
Todavia, é no contexto do processo de retirada do Afeganistão que surge o principal projeto da administração Obama em relação à região do Cáspio e seus recursos energéticos: a "New Silk Road Initiative" ${ }^{10}$ (NSRI) no qual, com o intuito de preparar uma política de transição à ocupação militar no Afeganistão, os EUA compreendiam que, para a manutenção da segurança do Afeganistão (e regional), seria necessário o fomento de um projeto de desenvolvimento - esperançosamente - viável (deste modo, transformando o Afeganistão em um núcleo geoeconômico deste projeto conectivo). (Boulegue 2015, 2; Frappi 2013, 197; Laruelle 2015, 364-5; Kiernan 2013, 37). O anúncio - simbólico — da iniciativa ocorreu através da então Secretária de Estado, Hillary Clinton, no dia 20 de julho de 2011 em Chennai (Índia). Em suas palavras:

Historicamente, as nações da Ásia Central e do Sul estavam conectadas umas às outras e ao resto do continente por uma extensa rede comercial chamada Rota da Seda [...]. Vamos trabalhar juntos para criar uma nova Rota da Seda. Não uma única via como o seu homônimo, mas uma rede internacional e rede de conexões econômicas e de trânsito. Isso significa construir mais linhas ferroviárias, rodovias, infraestrutura energética, como o gasoduto proposto para operar do Turcomenistão, através do Afeganistão, do Paquistão até a Índia (Clinton 2011. Tradução nossa).

No contexto da NSRI, o projeto do gasoduto da TurcomenistãoAfeganistão-Paquistão-Índia (TAPI) começou a receber apoio ativo dos EUA, se tornando peça central na política energética estadunidense para o Cáspio. Deste modo, o vetor geopolítico de Washington - antes voltado ao Corredor Meridional destinado à Europa - mudou gradativamente para o Sul asiático ao longo dos mandatos de Barack Obama. Ademais, um dos principais objetivos para a consolidação do TAPI era inviabilizar o fornecimento de gás iraniano para Índia e Paquistão - através do gasoduto Irã-Paquistão-Índia (IPI) (Frappi 2013, 197-9; Kiernan 2013, 37). Esta disputa de rotas pelo Sul asiático pode ser observada no Mapa 3 a seguir: 


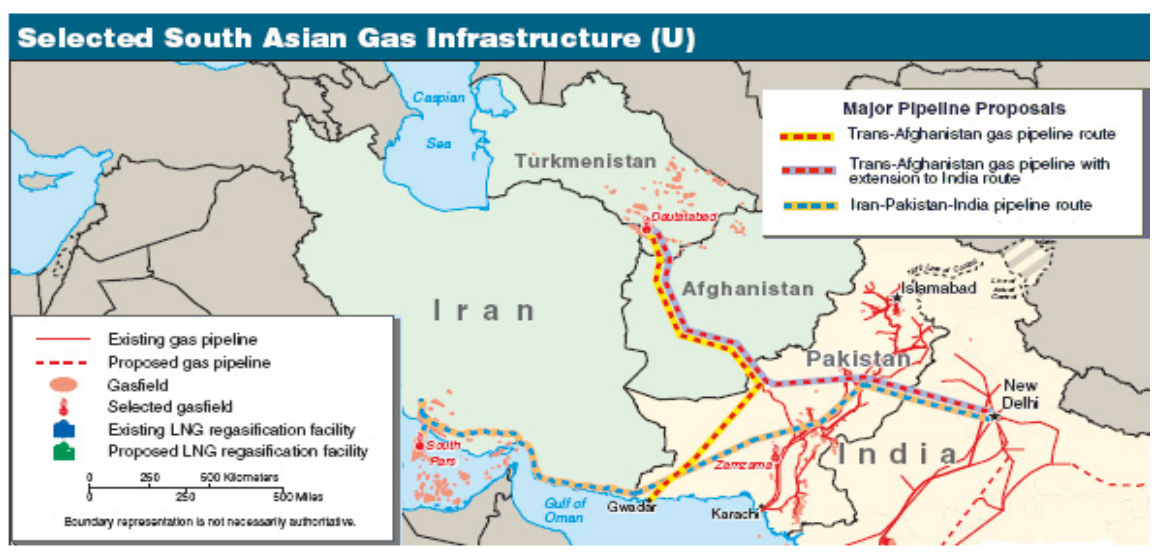

Mapa 3 - Projetos dutoviários concorrentes no Sul da Ásia.

Fonte: Global Security (2018).

Entretanto, a NSRI não conseguiu atingir os objetivos esperados na região do Cáspio. Apesar da forte retórica, os EUA não estavam dispostos a financiar a iniciativa em totalidade - a concepção estadunidense previa investimentos privados e dos países da região. Assim, sem a capitalização necessária, apoio político de alto nível, instituições estáveis, além de garantias securitárias, os resultados da NSRI foram decepcionantes. Ademais, a China, em 2013, anunciou um projeto conectivo muito mais ambicioso e promissor - com capacidade de investimentos gigantescas -, o One Belt, One Road (OBOR) (Frappi 2013, 201; Boulegue 2015, 2-3; Stronski, Rumer, and Sokolsky 2016, 19).

Dentre as qualidades da política energética externa chinesa, a estratégia de "petróleo por empréstimos" foi fundamental para firmar parcerias com os países do Cáspio. Através da concessão de créditos generosos concedidos pelos bancos estatais chineses - destinados sumariamente para grandes projetos de infraestrutura nestes países - e com pequenas taxas de juros, Pequim firma contratos de longo prazo para o recebimento de recursos energéticos. Deste modo, a estratégia chinesa garante longevidade na cooperação energética com a Região do Cáspio. Ademais, a analista de segurança internacional italiana, Lorena Di Placido, destaca que a China oferece oportunidades de negócio para seus potenciais parceiros muito mais tentadoras que suas contrapartes (EUA e U.E.), tais como a garantia de investimentos massivos em curtos períodos de tempo; apoio político incondicional aos países parceiros, através do princípio de não-interferência em assuntos internos e, se preciso, do poder de veto no Conselho de 
Segurança das Nações Unidas; e, acordos energéticos que abarcam outras áreas - economia, educação, tecnologia, etc. (Placido 2013, 216-7). "Por todas estas razões, a China é um elemento perturbador nas estratégias de marketing dos outros importadores extra-regionais" (Placido 2013, 217, tradução nossa).

Por fim, mas não menos importante, a atuação da Federação Russa foi grande impeditivo para as ambições estadunidenses na região. Afinal, o controle do mercado regional de gás é parte vital da estratégia geopolítica de Moscou em seu Exterior Próximo. Para tal, a Rússia utilizou-se de diversos instrumentos, tais como: firmando contratos de compra de longo prazo com os países produtores; participando - por meio de suas empresas estatais - na extração/produção de gás e petróleo da região; e ampliando sua rede dutoviária para permanecer como o principal operador de trânsito regional. Portanto, dificultando - ou inviabilizando - projetos dutoviários (alternativos) para a Europa. Ademais, Moscou garante sua influência na Região do Cáspio através de sua capacidade de competir com os novos sistemas de dutos propostos pelo Ocidente - esta dinâmica pode ser observada no Mapa - criando projetos análogos e oferecendo participação na produção e nos direitos de trânsito aos países europeus - o caso do gasoduto russo South Stream e contrário ao Nabucco (continuação do sistema BTC-BTE) é um exemplo claro (Terterov, Pool, and Nagornyy 2010, 195; Nygren 2012, 10; Lough 2011, 8).

\section{PLANNED SOUTH STREAM AND NABUCCO GAS PIPELINES}

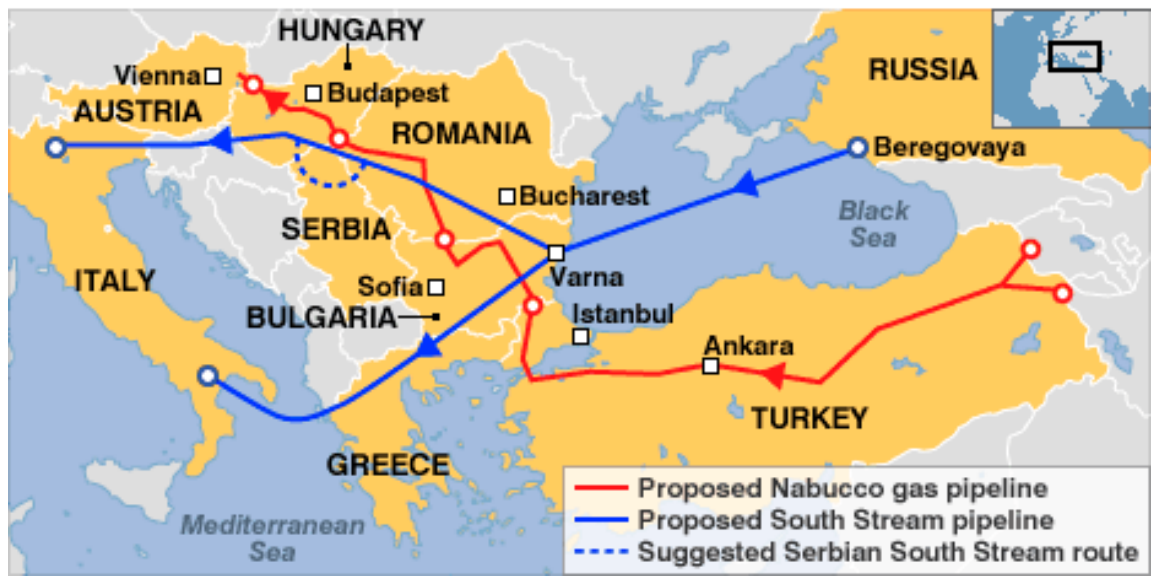

Mapa 4-Gasodutos conflitantes (South Stream vs Nabucco).

Fonte: BBC (2008). 


\section{CONCLUSÕES}

O EUA intensificaram sua presença política, econômica e militar na região do Cáspio a partir do início do século XXI movidos pela convergência de dois objetivos simultâneos de política externa: 1) ampliar o controle da produção global de petróleo, a fim de garantir a oferta de energia ao mercado mundial em volumes e preços compatíveis com a estabilidade financeira da ordem econômica liberal, e 2 ) reduzir a influência da Rússia no cenário geopolítico global, limitando o seu acesso às reservas energéticas (petróleo e gás natural) das antigas repúblicas que constituem o seu "Exterior Próximo" na região do Mar Cáspio de modo a viabilizar a exportação desses insumos diretamente a países enquadrados na área de influência dos EUA, notadamente a Geórgia e, em especial, a Turquia, com o objetivo de tornar os países da União Europeia importadores de energia russa menos dependentes desse suprimento, o que implicaria na diminuição da importância estratégica da Rússia.

Nesse sentido, os EUA estreitaram os laços de cooperação política e econômica com os governos do Azerbaijão e do Cazaquistão, ao mesmo tempo em que estimularam os investimentos de empresas petrolíferas ocidentais nesses países. Em paralelo, implementou-se construção de gasoduto Baku-Tbilisi-Ceyhan, que conduz gás natural procedente do Azerbaijão, Cazaquistão e outros Estados da Ásia Central para um porto na Turquia, atravessando a Geórgia. Esse gasoduto é um empreendimento pouco atraente do ponto de vista financeiro, devido aos seus custos elevados em comparação com os (relativamente) modestos rendimentos comerciais decorrentes da operação, mas que se justifica do ponto de vista político, já que viabiliza o transporte de recursos energéticos da Ásia Central para o Ocidente sem a necessidade de passar por território russo. Outro projeto estadunidense no sentido de facilitar o escoamento de recursos energéticos da região do Cáspio para o mercado global sem passar pela Rússia nem pelo Irã era o gasoduto Turcomenistão-Afeganistão-Paquistão-Índia (TAPI), um empreendimento altamente ambicioso para cuja concretização seria indispensável a estabilização política do Afeganistão, com uma vitória militar dos EUA e seus aliados sobre os guerrilheiros talibãs ou, ao menos, um acordo de paz em termos compatíveis com os interesses ocidentais.

$\mathrm{Na}$ administração Obama, contudo, ocorreu uma mudança nas prioridades estratégicas dos EUA. O novo presidente reverteu a escalada de conflitos com a Rússia (a chamada "Nova Guerra Fria”) e passou a cooperar (inicialmente) com os dirigentes russos em certos temas da agenda internacional, como o combate ao terrorismo e as negociações com o Irã sobre a proliferação nuclear. O foco das preocupações de Washington se voltou pa- 
ra a China, com a intensificação das tensões militares no Extremo Oriente. Outra guinada na estratégia estadunidense durante o governo Obama refere-se ao Afeganistão, com a adoção de iniciativas voltadas para o desengajamento militar em relação àquele conflito. Ao mesmo tempo, a garantia da segurança energética global e controle das reservas de petróleo teve sua importância rebaixada nas prioridades da política externa dos EUA diante do aumento significativo da produção estadunidense de petróleo e de gás natural pelo método revolucionário do fracionamento hidráulico, que reduziu a vulnerabilidade dos EUA e de seus aliados a uma eventual queda dos suprimentos energéticos dos fornecedores tradicionais.

Nesse novo contexto, a região do Cáspio deixou de ser considerada uma prioridade estratégica do ponto de vista de Washington, o que levou à redução dos investimentos econômicos, políticos e militares dos EUA na região do Cáspio, abrindo caminho para a crescente influência da China e reafirmação da Rússia naquele cenário geopolítico.

\section{REFERÊNCIAS}

Abilov, Shamkhal. 2012. "The 'New Great Game' Over the Caspian Region: Russia, the USA, and China in the Same Melting Pot". Khazar Journal of Humanities and Social Sciences 15, no. 2: 29-60.

Abraham, Spencer. 2001. Remarks by U.S Secretary of Energy, realizado perante a Câmera de Comércio dos Estados Unidos, 19 mar. http://cheniere.org/briefings/ energysec/index.html.

Aydin, Mustafa. 2004. Oil, Pipelines and Security: The. Geopolitics of the Caspian Region, in: The Caspian. Region: A Re-emerging Region, 1. (ed) Moshe. Gammer London; New York: Routledge.

BBC. 2008. Gasodutos conflitantes (South Stream vs Nabucco). Figura. Londres. http://news.bbc.co.uk/2/hi/europe/7799396.stm.

Benke, Ildiko. 2010. "Power and Energy: Geopolitical Aspects of the Transnational Natural Gas Pipelines from the Caspian Sea Basin to Europe". 73 f. Dissertação (Mestrado) - Curso de Geopolítica. Monterey: Naval Postgraduate School.

Blank, Stephen. 2014. "From Eurasia with Love". American Foreign Policy Interests, 36:3, 162-174, DOI: 10.1080/10803920.2014.925338.

Boulegue, Mathieu. 2015. "U.S. engagement towards Central Asia: no Great Game after all?”. Chroniques Américaines (October). https://www.ifri.org/en/pu- 
blications/editoriaux/chroniques-americaines/us-engagement-towards-central-asia-no-great-game.

BP. 2017. British Petroleum Statistical Review of World Energy.

2018. Caspian: Operations and projects. https://www.bp.com/en_az/caspian/operationsprojects.html.

Brands, Hal. 2016. American Grand Strategy and the Liberal Order Continuity, Change, and Options for the Future. Washington, D.C: Rand Corporation.

Brzezinski, Zbigniew. 1997. The Grand Chessboard: American Primacy and Its Evidence from Cases. New York: Basic Books.

Bunder, Tulio. 2018. "Sobre hidrocarbonetos e invólucro por potências: as dinâmicas geopolíticas da região do Cáspio”. Hoplos 1, no. 2: 46-62. ISSN: 2595-699X.

Bush, George W. 2005. President Addresses and Thanks Citizens, realizado em Tbilisi, Georgia. 10 may. georgewbush-whitehouse.archives.gov/news/releases/2005/05/20050510-2.html.

2006. State of the Union, realizado perante o Congresso dos Estados Unidos, 31 jan. http://www.presidency.ucsb.edu/ws/index.php?pid=65090.

Carter, Jimmy. 1980. State of the Union, realizado perante o Congresso dos Estados Unidos, 23 jan. http://www.presidency.ucsb.edu/ws/?pid=33079.

Chomsky, Noam. 2003. Hegemony or Survival - America's Quest for Global Dominance. New York: Metropolitan Books.

Chow, Edward C., and Leigh E. Hendrix. 2010. "Central Asia's Pipelines: Field of Dreams and Reality". The National Bureau of Asian Research, no. 23 (September): 29-42. Washington.

Clinton, Hilary. 2011. Remarks on India and the United States: A Vision for the 21st Century, realizado em Anna Centenary Library, Chennai - Índia, no dia 20 de julho de 2011. https://2009-2017.state.gov/secretary/20092013clinton/ $\mathrm{rm} / 2011 / 07 / 168840 . h t m$.

Cohen, Ariel. 2012. US Interests and Policy in Post-Soviet Eurasia, testemunho perante ao Subcomitê Europa e Eurasia do Comitê de Relações Internacionais do Congresso dos EUA, 24 julho.

Cornell, S. E. M. Tsereteli, and V. Socor, 2006. Geostrategic Implications of the Baku-Tbilisi-Ceyhan Pipeline. OGEL. 
Department of Defense. 2009. Dictionary of Military and Associated Terms. 2. ed. Washington Dc: Department of Defense. 777 p. https://web.archive.org/ web/20100310102614/http://www.dtic.mil/doctrine/new_pubs/jp1_02.pdf.

Donilon, Tom. 2013. "United States Energy: Energy and American Power Farewell to Declinism". Foreign Affairs. Nova Iorque. https://www.foreignaffairs. com/articles/united-states/2013-06-15/energy-and-american-power.

EIA. 2017. International Energy Outlook.

Engdahl, William. 1992. A Century of War: Anglo-American oil politics and the new world order. London Ann Arbor, MI: Pluto Press.

2009 Full Spectrum Dominance: Totalitarian Democracy in the Nerw World. Wiesbaden: edition.engdahl.

Escobar, Pepe. 2005. Central Asian Nerws and current affairs, Russia, Afghanistan, Uzbekistan: Pipelineistan's biggest game begins. https://www.asiatimes.com/atimes/ Central_Asia/GE26Ago1.html.

Frappi, Carlo. 2013. The Caspian Sea Chessboard: Geo-political, geo-strategic and geo-economic analysis. Milano: Egea.

Fuser, Igor. 2005. "O petróleo e o envolvimento militar dos Estados Unidos no Golfo Pérsico”. 330f. Dissertação (Mestrado em Relações Internacionais) Universidade Estadual Paulista Júlio de Mesquita Filho, UNESP, Brasil. 2013. Energia e Relações Internacionais. São Paulo: Saraiva.

Gaddis, John L. 2018. On Grand Strategy. New York: Penguin Press.

Garashova, Sabina. 2010. "On Certain Aspects of the U.S. Caspian's Strategy". The Caucasus \& Globalization. Baku 4, no. 3-4: 29-34.

2014. "U. S. geopolitical trends in the Caspian region". The Caucasus $\&^{\circ}$ Globalization 8, no. 3-4: 24-32.

Global Security. 2018. Projetos dutoviários concorrentes no Sul da Ásia. Figura. https://www.globalsecurity.org/military/world/pakistan/cpec.htm.

Gray, Colin S. 2007. War, peace, and international relations: an introduction to strategic history. London, New York: Routledge. 
Gvosdev, Nikolas. 2013. The Realist Prism: For U.S., Keeping Ukraine on Side No Longer a Vital Interest. https://www.worldpoliticsreview.com/articles/13440/ the-realist-prism-for-u-s-keeping-ukraine-on-side-no-longer-a-vital-interest.

Heritage. 2016. Oleoduto BTC. Figura. https://www.heritage.org/middle-east/ report/the-nagorno-karabakh-conflict-us-vigilance-required.

Hooker, R. D. 2016. Charting a Course: Strategic Choices for a New Administration. Washington, D.C.: U.S. National Defense University Press.

Khalifazadeh, M.. 2014. “The Obama Administration's Russia 'Reset' Policy and the Southern Caucasus". Central Asia and the Caucasus 15: 78-91.

Kiernan, Peter (Org.). 2013. "The Great Game for Gas in the Caspian: Europe opens the southern corridor". The Economist (June): 3-40. New York.

Klare, Michael. 2001. Resource Wars: The New Landscape of Global Conflict. Nova York: Metropolitan.

2004. Blood and Oil: How America's thirst for petrol is killing us. London: Penguin Books.

2011. Playing with Fire: Obama's Risky Oil Threat to China. https://www. thenation.com/article/archive/playing-fire-obamas-risky-oil-threat-china/.

Kostianoy, Andrey G., Igor S. Zonn, and Evgeniia A. Kostianaia. 2016. “Geographic Characteristics of the Black-Caspian Seas Region”. In Oil And Gas Pipelines In The Black-Caspian Seas Region, edited by Sergey S. Zhiltsov, Igor S. Zonn, and Andrey G. Kostianoy. Moscou: Springer. 7-37.

Kubicek, P. 2013. "Energy politics and geopolitical competition in the Caspian Basin”. Journal of Eurasian Studies 4, no. 2, p. 171-80.

Ladislaw, Sarah O., Maren Leed, and Molly A. Walton. 2014. "New Energy, New Geopolitics: Balancing Stability and Leverage". Center for Strategic International Studies, 1 abril: 393-4. Washington.

Laruelle, M. 2015. "The US Silk Road: geopolitical imaginary or the repackaging of strategic interests?" Eurasian Geography and Economics 56, no. 4, p. 360-75. http://dx.doi.org/10.1080/15387216.2015.1098555.

Lehmann, Timothy C. 2017. The Geopolitics of Global Energy: The New Cost of Plenty. Boulder, Colorado: Lynne Rienner Publishers, 1-22. 
Lough, John. 2011. Russia's Energy Diplomacy. 16 p. (The Means and Ends of Russian Influence Abroad Series). Londres: Chatham House.

Mahdi, A.S.S. 2010. US Foreing Policy and Energy Resources during the George W. Bush administration. Birmingham: Department of American and Canadian Studies.

Mammadov, Ilgar. 2009. Geopolitics of Energy in the Caspian Sea Region. Massachusetts: The Fletcher School.

Misiagiewicz, Justyna. 2012. "Geopolitics and Energy Security in the Caspian Region". Teka Commission of Protection and Formation of Natural Environment 7, no. 1 (April): 61-79. Lublin.

Morris, Katherine-Anne. 2015. Oil, Power, and Global Hegemony. 2015. 117 f. Dissertação (Mestrado) — International Studies, Stellenbosch University, Stellenbosch.

National Energy Policy. 2001. "NEP — Reliable, Affordable, and Environmentally Sound Energy for America's Future". Report of the National Energy Policy Development Group. Washington: National Energy Policy Development Group. http://www.wtrg.com/EnergyReport/National-Energy-Policy.pdf.

Nygren, Bertil. 2008. "Putin's Use of Natural Gas to Reintegrate the CIS Region". Problems of Post-Communism [s. 1.] 55, no. 4, 3-15. http://dx.doi.org/10.2753/ PPC1075-8216550401.

2012. "Russian Resource Policies towards the CIS Countries". In Russia and its Near Neighbours: Identity, Interests and Foreign Policy, edited by Maria Raquel Freire et al. Nova Iorque: Palgrave Macmillan. 223-247.

Oktav, Özden Zeynep. 2005. "American Policies Towards the Caspian Sea and The Baku-Tbilisi-Ceyhan Pipeline”. Sage-Perception 3, no. 2 (May): 17-34.

Pagliarulo, Diego. 2016. "Smart Geopolitics, Dangerous Ideas: Energy security, Ideology, and the Challenges of American Policy in the Persian Gulf". European Journal of American Studies 11, no. 2: 1-55 (August). Bruxelas.

Placido, Lorena di. 2013. 'Chinese 'Good Neighborhood Policy' and Energy Diplomacy toward the Caspian Sea”. InThe Caspian Sea Chessboard: Geo-political, geo-strategic and geo-economic analysis, edited by Carlo Frappi and Azad Garibov. Milão: Egea.

Posen, B., 2014. Restraint: A New Foundation for U.S. Grand Strategy. 1. ed. Cornell University Press. 
Raphael, S., and D. Stokes. 2014. US oil strategy in the Caspian Basin: Hegemony through interdependence. International Relations [s.l.] 28, no. 2: 183-206, 12 maio.

Rumer, Eugene, Richard Sokolsky, and Paul Stronski. 2016. U.S. Policy Toward Central Asia 3.0. 3. ed. Lancaster: Carnegie Endowment for International Peace.

Sébille-López, Philippe. 2006. Geopolíticas do petróleo. Lisboa: Instituto Piaget.

Socor, Vladimir. 2005. "Baku-Tbilisi-Ceyhan Oil Pipeline Inaugurated”. Eurasia Daily Monitor 2, no. 105. https://jamestown.org/program/baku-tbilisi-ceyhan-oil-pipeline-inaugurated.

Terterov, M., J. Van Pool, and S. Nagornyy. 2010. "Russian Geopolitical Power in the Black and Caspian Seas Region: Implications for Turkey and the World". Insight Turkey 12, no. 3: 191-203.

UNEP. 2008. Político e Topográfico da Região do Cáspio. Figura. United Nations Environment Programme. http://www.envsec.org/maps/01.jpg

Yergin, Daniel. 1991. The Prize: The Epic Quest for Oil, Money, and Power. Nova York: Simon \& Schuster.

. 2006. Ensuring Energy Security. Foreign Affairs, Nova Iorque, 1 mar. https://www.foreignaffairs.com/articles/2006-03-01/ensuring-energy-security. 


\section{NOTAS}

1. Termo da Geografia para definir qualquer acumulação significativa de água. Geralmente refere-se a grandes acumulações de água, tais como oceanos, mares e lagos.

2. Para uma compreensão ampla/macro das disputas geopolíticas na região do Cáspio, ver Bunder (2018).

3. A ordem internacional é o conjunto de regras, normas e instituições que regem as relações entre os principais atores do ambiente internacional.

4. Se compreende o conceito de hegemonia como: primazia/liderança em um ordenamento internacional - essa primazia seria exercida por um Estado com capacidade suficiente para cumprir esse papel (hegemon). Para tal, os demais Estados devem definir suas relações/interpretações - condescendentes, indiferentes ou antagônicos - em relação ao hegemon. Assim, se a maioria dos entes estatais do sistema internacional admitir a liderança e as regras impostas — através do chamado "consentimento hegemônico" - a hegemonia entra em vigor.

5. Bush teve mais laços com a indústria de energia do que qualquer outro governante norte-americano na história, visto que ele foi um executivo do ramo petrolífero (embora não muito bem-sucedido), tendo fundado a Arbusto, fundindo-a com o Spectrum 7, e, por fim, trabalhou na Harken Energy (Mahdi 2010, 18).

6. Também conhecida como "Full-Spectrum Superiority" (Superioridade do Espectro Completo, tradução nossa) é o efeito cumulativo de uma posição dominante no ar, terra, marítima e nos domínios espaciais, e também no campo das informações (que inclui o ciberespaço), permitindo a realização de operações conjuntas sem oposição eficaz ou interferência proibitiva (Department of Defense 2009, 220).

7. Ilham Heydar oglu Aliyev é o atual presidente do Azerbaijão, cargo que ocupa desde 2003 - sucedendo a seu pai Heydar Alirza oglu Aliyev.

8. Ou "taxa de transferência" de um duto.

9. Think-tank estadunidense com ligações com a OTAN.

10. "Iniciativa da Nova Rota da Seda" em português. 


\section{A REGIÃO DO CÁSPIO NA ESTRATÉGIA GLOBAL DOS EUA: DO ENGAJAMENTO À RETIRADA}

\section{RESUMO}

O trabalho busca analisar a presença política e econômica dos Estados Unidos na região do Cáspio durante os governos de George W. Bush (2000-2008) e de Barack Obama (2009-2016), abordando a relação entre o poder estadunidense e os recursos energéticos no contexto da Grande Estratégia.

Palavras chave: Estados Unidos; Segurança Energética; Região do Cáspio; Geopolítica da Energia.

\section{ABSTRACT}

The article seeks to analyze the political and economic presence of the United States in the Caspian region during the governments of George W. Bush (2000-2008) and Barack Obama (2009-2016), addressing the relationship between US power and energy resources in the context of the Grand Strategy.

Keywords: United States of America; Energy Security; Caspian Region; Energy Geopolitics. 